\title{
Apparent digestibility coefficient of chickpea, maize, high-quality protein maize, and beans diets in juvenile and adult Nile tilapia (Oreochromis niloticus)
}

\author{
Magnolia Montoya-Mejía', Alfredo Hernández-Llamas², Manuel García-Ulloa', Héctor \\ Nolasco-Soria ${ }^{2}$, Roberto Gutierrez-Dorado ${ }^{3}$, Hervey Rodríguez-González ${ }^{1}$
}

\footnotetext{
${ }^{1}$ Instituto Politécnico Nacional, Centro Interdisciplinario de Investigación para el Desarrollo Integral Regional, Guasave, Sinaloa, México.

${ }^{2}$ Centro de Investigaciones Biológicas del Noroeste S.C., La Paz, Baja California Sur, México.

${ }^{3}$ Universidad Autónoma de Sinaloa, Culiacán, Sinaloa, México.
}

\begin{abstract}
The objective of our study was to assess the apparent digestibility of plant ingredients in diets for juvenile $(50 \mathrm{~g})$ and adult $(220 \mathrm{~g})$ Nile tilapia (Oreochromis niloticus). Dietary dry matter and protein apparent digestibility coefficients of four plant-derived feedstuffs (chickpea, maize, high-quality maize protein, and beans) were tested. The beans diet had the lowest apparent digestibility coefficient of dry matter $\left(\mathrm{ADC}_{\mathrm{DM}}\right)(69.41 \%)$, while no significant differences were detected in $\mathrm{ADC}_{\mathrm{DM}}$ among the other diets; $\mathrm{ADC}_{\mathrm{DM}}$ was significantly higher in adults compared with juveniles (77.02 vs. 73.76\%). Apparent dry matter digestibility coefficient of ingredients $\left(\mathrm{ADC}_{\mathrm{I}}\right)$ was significantly higher in the chickpea $(70.48 \%)$ and high-quality protein maize $(71.09 \%)$ ingredients, and lower in the beans $(52.79 \%)$ ingredient. Apparent dry matter digestibility coefficient of ingredients was significantly higher in juveniles compared with adults (72.56 vs. $56.80 \%)$. The protein digestibility of diet $\left(\mathrm{ADC}_{\mathrm{CP}}\right)$ was significantly higher in the reference diet $(93.68 \%)$, while the lowest corresponded to the maize $(87.86 \%)$ and beans $(87.29 \%)$ diets. Significantly lower apparent digestibility coefficient of protein $\left(\mathrm{ADC}_{\mathrm{ICP}}\right)$ was obtained with the highquality maize protein $(59.11 \%)$ and maize $(49.48 \%)$ ingredients, while higher $\mathrm{ADC}_{\mathrm{ICP}}$ was obtained with the chickpea and beans ingredients (71.31 and $63.89 \%$, respectively). The apparent digestibility coefficient of ingredient crude protein $\mathrm{ADC}_{\mathrm{ICP}}$ was significantly higher in juveniles compared with adults (67.35 vs. 53.46). Digestibility is generally higher in juveniles, and we recommend using chickpea as an ingredient in diets for Nile tilapia.
\end{abstract}

Key Words: adults, feedstuffs, in vivo digestibility, juveniles, plant ingredients

\section{Introduction}

Diets for fish are usually formulated with different animal and plant ingredients. Animal-derived ingredients are mainly used to satisfy protein requirements, particularly of carnivorous species. These ingredients are generally more expensive, scarce, and less available than ingredients of plant origin (Chamberlain, 1995). Various protein sources, such as coffee pulp (Ulloa Rojas and Verreth, 2003), leucaena leaf meal (Wee and Wang, 1987), cottonseed meal (Lee and Dabrowski, 2002), moringa (Richter et al., 2003), and torula yeast (Olvera-Novoa et al., 2002) have been studied as ingredients in diets for tilapia.

According to FAO Stat (2015), with $1000 \mathrm{Mt}$, corn is one of the cereals with highest production worldwide,

Received December 11, 2015 and accepted April 7, 2016.

Corresponding author: hervey23@hotmail.com

http://dx.doi.org/10.1590/S1806-92902016000800001

Copyright (c) 2016 Sociedade Brasileira de Zootecnia. This is an Open Access article distributed under the terms of the Creative Commons Attribution License (http://creativecommons.org/licenses/by/4.0/), which permits unrestricted use, distribution, and reproduction in any medium, provided the original work is properly cited. while legumes production is $42 \mathrm{Mt}$, with more than a half corresponding to beans and $12 \mathrm{Mt}$ to chickpea. Corn, chickpea, and beans are highly available low-cost products in the international market. In his review on the use of plant protein sources in fish diets, Hardy (2010) stressed that, despite the rapid increases in prices of plant meals, the cost per unit protein for plant protein sources remained lower than that of fishmeal protein.

The most important characteristic of any feedstuff is bioavailability, particularly digestible protein, available amino acids, and digestible energy. Understanding the digestibility of ingredients is a basic requirement for diet formulation (Cho and Kaushik, 1990). Coefficients of apparent digestibility provide estimates of nutrient availability in feedstuffs and are used to select ingredients that optimize nutritional value and cost of formulated diets (Fagbenro, 1999). Among the factors known to affect nutrient digestibility in fish are the species, feed size, frequency of feeding, and fish size/age (De Silva and Perera, 1983; Henken et al., 1985; Usmani and Jafri, 2002). He et al. (2013) found that digestibility decreased as the size of Nile tilapia increased. Our objective was to assess 
the effect of size of Nile tilapia (juvenile and adult) on the apparent digestibility coefficient of chickpea, maize, highquality protein maize, and beans as ingredients in diets. There are no studies on the digestibility of these ingredients in Nile tilapia.

\section{Material and Methods}

The feeding trial was conducted in Guasave, Sinaloa, México. Four plastic tanks (40 L) per treatment were used and supplied with filtered, sterilized freshwater. The tanks were covered with plastic mesh to prevent escape of fish. Cultivation conditions were: photoperiod of $14 \mathrm{~h}$ light: $10 \mathrm{~h}$ dark, $27 \pm 1{ }^{\circ} \mathrm{C}$, and dissolved oxygen $>4 \mathrm{mg} / \mathrm{L}$.

Five diets were prepared (Table 1). One was a reference diet (30\% crude protein, CP; and $8 \%$ lipids, LIP) and four were experimental diets. The experimental diets contained $69.0 \%$ of the ingredients of the reference diet, $30 \%$ of the tested ingredient, and $1 \%$ chromium oxide as a marker. The ingredients were ground with a mill (Laboratory Mill 3610, Perten Instruments, Hägersten, Sweden) and sieved through a $460 \mu \mathrm{m}$ mesh. Diets were prepared with an extruder and dried at $45{ }^{\circ} \mathrm{C}$ until their moisture content was $8-10 \%$. Afterwards, pellets were ground to a size appropriate for the size of fish, and stored at $-20{ }^{\circ} \mathrm{C}$ until required. Triplicate samples of each diet were used for chemical analysis. The tested ingredients were chickpea (Cicer arietinum) variety Blanco Sinaloa 92, white maize (Zea mays), high-quality maize protein (HQMP), and azufrado (sulphur yellow) beans (Phaseolus vulgaris). The diets were analysed for their proximate composition (Table 1) by standard methods (AOAC, 1995) and for their energy content, using an adiabatic calorimeter (PARR, Moline, Illinois, USA). Juvenile $(50 \pm 2 \mathrm{~g})$ and adult $(220 \pm 5 \mathrm{~g})$ tilapia were used. Each experimental tank $(0.50 \times 0.35 \times 0.30 \mathrm{~m}$; total of 40$)$ was stocked with one fish obtained from the CIIDIR-IPN hatchery. Four tanks per diet were randomly assigned. Tilapias were acclimated to the experimental conditions for one week, consuming the reference diet to apparent satiation, which was delivered twice daily (08.00 and $16.00 \mathrm{~h})$. After acclimation, fish were fed to apparent satiation twice daily (08.00 and $16.00 \mathrm{~h}$ ), for 54 days. Faeces were collected from each tank three hours after each feeding, using a Pasteur pipette with a siphon (Jones and De Silva, 1997). Faeces were rinsed with distilled water, lyophilized, and stored at $-70{ }^{\circ} \mathrm{C}$ until further analysis. Protein and chromic oxide in the faeces and diets were evaluated simultaneously by the method of Bolin et al. (1952), a modified micro-Kjieldahl method (Nieto et al., 1997).

The percentage of apparent dry matter digestibility $\left(\mathrm{ADC}_{\mathrm{DM}}\right)$ and apparent protein digestibility $\left(\mathrm{ADC}_{\mathrm{CP}}\right)$ were calculated using the equations of Maynard et al. (1979), cited by Cruz-Suarez et al. (2001): $\% \mathrm{ADC}_{\mathrm{DM}}=100-100 \times\left[\left(\% \mathrm{Cr}_{2} \mathrm{O}_{3}\right.\right.$ in diet $) /\left(\% \mathrm{Cr}_{2} \mathrm{O}_{3}\right.$ in faeces $\left.)\right]$ $\% \mathrm{ADC}_{\mathrm{CP}}=100-100 \times\left[\left(\% \mathrm{Cr}_{2} \mathrm{O}_{3}\right.\right.$ in diet $) /(\% \mathrm{CP}$ in diet $\left.)\right]$ $\times\left[(\% \mathrm{CP}\right.$ in faeces $) /\left(\% \mathrm{Cr}_{2} \mathrm{O}_{3}\right.$ in faeces $\left.)\right]$, in which $\mathrm{CP}$ is the crude protein content. The percentage of apparent dry matter and protein digestibility of ingredients

Table 1 - Formulation and proximal composition of experimental diets for O. niloticus

\begin{tabular}{|c|c|c|c|c|c|}
\hline \multirow{2}{*}{ Ingredient } & \multicolumn{5}{|c|}{$\operatorname{Diet}^{1}(\mathrm{~g} / \mathrm{kg})$} \\
\hline & 1 & 2 & 3 & 4 & 5 \\
\hline Fish meal & 200 & 137 & 137 & 137 & 137 \\
\hline Wheat bran & 562 & 391 & 391 & 391 & 391 \\
\hline Soy paste & 127 & 90 & 90 & 90 & 90 \\
\hline Gelatine & 39 & 28 & 28 & 28 & 28 \\
\hline Fish oil & 24 & 17 & 17 & 17 & 17 \\
\hline Soy lecithin & 24 & 17 & 17 & 17 & 17 \\
\hline Vitamin and mineral mixture ${ }^{2}$ & 14 & 10 & 10 & 10 & 10 \\
\hline Chromium oxide & 10 & 10 & 10 & 10 & 10 \\
\hline Chickpea meal & - & 300 & - & - & - \\
\hline Maize QPM meal & - & - & 300 & - & - \\
\hline Maize meal & - & - & - & 300 & - \\
\hline Bean meal & - & - & - & - & 300 \\
\hline Crude protein ${ }^{3}$ & $308.2 \pm 3.3$ & $280 \pm 1.2$ & $245.3 \pm 2.5$ & $246.2 \pm 1.0$ & $298.5 \pm 1.1$ \\
\hline Ether extract ${ }^{3}$ & $78.8 \pm 0.5$ & $76.8 \pm 0.5$ & $72.1 \pm 0.2$ & $75.7 \pm 0.5$ & $58.1 \pm 1.2$ \\
\hline $\mathrm{Ash}^{3}$ & $68.6 \pm 0.4$ & $62.7 \pm 0.1$ & $58.9 \pm 0.3$ & $58.9 \pm 0.2$ & $66.5 \pm 0.4$ \\
\hline Crude fiber ${ }^{3}$ & $2.9 \pm 0.4$ & $7.7 \pm 0.4$ & $4.5 \pm 0.6$ & $5.0 \pm 0.9$ & $9.4 \pm 0.7$ \\
\hline $\mathrm{N}$-free extract ${ }^{3}$ & 541.6 & 572.8 & 619.3 & 614.8 & 567.4 \\
\hline Energy (kJ/g) & $18.48 \pm 0.04$ & $17.3 \pm 0.05$ & $18.17 \pm 0.04$ & $17.35 \pm 0.04$ & $17.70 \pm 0.05$ \\
\hline
\end{tabular}

${ }^{1}$ Diets: 1 - reference diet; 2 - diet with $30 \%$ chickpea meal; 3 - diet with 30\% maize QPM meal; 4 - diet with $30 \%$ maize meal; and 5 - diet with $30 \%$ beans meal.

${ }^{2}$ Vitamin and mineral mixture $(\mathrm{g} / \mathrm{kg}$ feed): thiamine, 0.011 ; folic acid, 0.005 ; riboflavin, $0.02 ;$ pyridoxine, $0.011 ;$ choline, $0.275 ;$ pantothenic acid, $0.0035 ;$ niacin, $0.088 ;$ vitamin B12, 0.00001; vitamin K, 0.0044; vitamin D3, 0.000055; vitamin E, 0.04422; ascorbic acid 0.375; calcium, 3.0; phosphorous, 7.0; magnesium, 0.5; iodine, 0.001; iron, 0.15; copper, 0.003; zinc, 0.20; manganese, 0.013; selenium, 0.0004 .

${ }^{3}$ Dry matter $\left(\mathrm{g} \mathrm{kg}^{-1}\right)$, mean \pm standard deviation, $\mathrm{n}=3$. 
was determined by the method described by Cho and Slinger (1979), as follows:

$$
\begin{gathered}
\% \mathrm{ADC}_{\mathrm{I}}=\left[\left(100 \times \% \mathrm{ADC}_{\mathrm{DM}} \text { of TD }\right)-((100-\% \mathrm{TI}) \times\right. \\
\left.\left.\% \mathrm{ADC}_{\mathrm{DM}} \text { of } \mathrm{RD}\right)\right] /(\% \mathrm{TI}) \\
\% \mathrm{ADC}_{\mathrm{ICP}}=\left[\left(100 \times \% \mathrm{ADC}_{\mathrm{CP}} \text { of TD } \times \% \mathrm{CP} \text { in } \mathrm{TD}\right)-((100\right. \\
\left.\left.-\% \mathrm{TI}) \times \% \mathrm{ADC}_{\mathrm{CP}} \text { of } \mathrm{RD} \times \% \mathrm{CP} \text { in } \mathrm{RD}\right)\right] /(\% \mathrm{TI} \times \% \mathrm{CP} \text { in } \mathrm{TI}),
\end{gathered}
$$

in which $\mathrm{ADC}_{\mathrm{I}}$ is the apparent dry matter digestibility of the ingredient; $\mathrm{ADC}_{\mathrm{DM}}$ of $\mathrm{TD}$ is the apparent dry matter digestibility of the tested diet; TI is the tested ingredient; $\mathrm{ADC}_{\mathrm{DM}}$ of $\mathrm{RD}$ is the apparent dry matter digestibility of the reference diet; $\mathrm{ADC}_{\mathrm{ICP}}$ is the apparent protein digestibility of the ingredient; $\mathrm{ADC}_{\mathrm{CP}}$ of $\mathrm{TD}$ is the apparent protein digestibility of the tested diet; $\mathrm{CP}$ in TD is the concentration of protein in the tested diet; TI is the tested ingredient; $\mathrm{ADC}_{\mathrm{CP}}$ of $\mathrm{RD}$ is the apparent protein digestibility of the reference diet; $\mathrm{CP}$ in $\mathrm{RD}$ is the concentration of protein of the reference diet; and $\mathrm{CP}$ in $\mathrm{TI}$ is the concentration of protein in the tested ingredient.

A two-factor, completely randomized experimental design, with four replicates per treatment, was used. Values of digestibility were tested for normality and variance homogeneity. A two-way ANOVA and a Tukey's multiplerange test were used to compare means values of digestibility of diets and ingredients among juveniles and adults. Diets and the size of the fish were the main factors in the two-way ANOVA. Statistica 7.0 software (StatSoft, Tulsa) was used for the tests, with significance set at $\mathrm{P}<0.05$.

\section{Results}

There were significant differences in $\mathrm{ADC}_{\mathrm{DM}}$ among diets and among juveniles and adults. No significant interaction between the main factors was detected. Apparent digestibility coefficients of dry matter varied from $71.32 \%$ (beans diet) to $74.86 \%$ (chickpea diet) in juveniles, and from $67.5 \%$ (beans diet) to $85.37 \%$ (reference diet) in adults. A significant lower value of $\mathrm{ADC}_{\mathrm{DM}}$ was detected in the beans diet, while no significant differences were detected among the other diets (Figure 1a). Apparent digestibility coefficient of dry matter was significantly higher in adults (Figure 1b). There were significant differences in $\mathrm{ADC}_{\mathrm{I}}$ among diets and among juveniles and adults. No significant interaction between the main factors was detected. Apparent dry matter digestibility coefficients of ingredients varied from $60.92 \%$ (beans diet) to $76.33 \%$ (chickpea diet) in juveniles, and from $44.67 \%$ (beans diet) to $64.64 \%$ (chickpea diet) in adults. Values of $\mathrm{ADC}_{\mathrm{I}}$ were significantly higher in the chickpea and maize QPM diets, and lower in the beans diet (Figure 2a). Apparent dry matter digestibility coefficient of

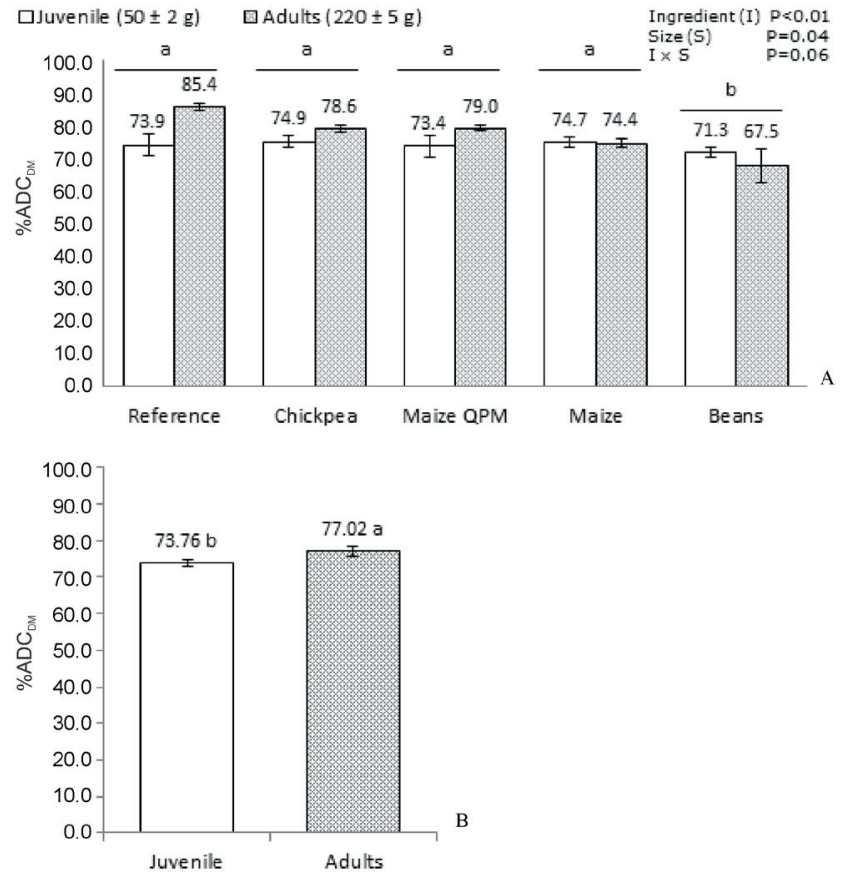

Results of the two-way ANOVA are included in the figure. Means followed by different letters are significantly different.

Figure 1 - Effect of diets (A) and tilapia size (B) on apparent digestibility coefficient of dry matter $\left(\% \mathrm{ADC}_{\mathrm{DM}}\right)$.

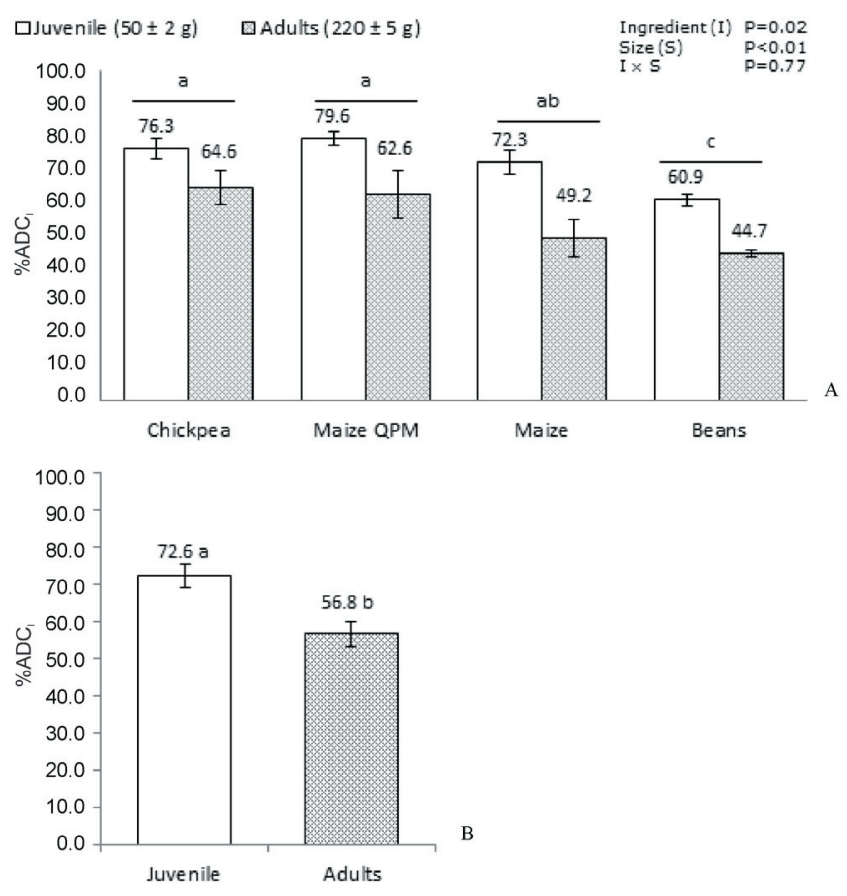

Results of the two-way ANOVA are included in the figure. Means followed by different letters are significantly different.

Figure 2 - Effect of diets (A) and tilapia size (B) on apparent digestibility coefficient of ingredients $\left(\% \mathrm{ADC}_{\mathrm{I}}\right)$. 
ingredients was significantly higher in juveniles (Figure 2b). There were significant differences in $\mathrm{ADC}_{\mathrm{CP}}$ among diets, but no significant difference was detected between juveniles and adults. No significant interaction between the main factors was detected. Apparent digestibility coefficients of crude protein varied from $86.94 \%$ (beans diet) to $92.73 \%$

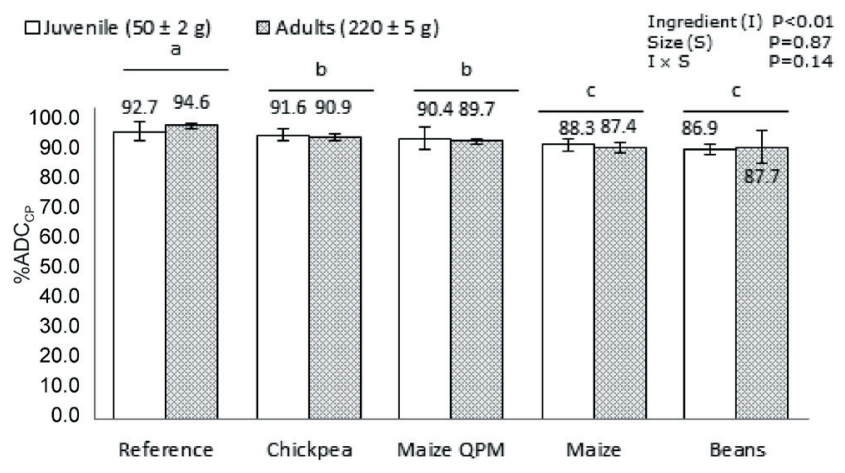

Results of the two-way ANOVA are included in the figure. Means followed by different letters are significantly different.

Figure 3 - Effect of diets on apparent digestibility coefficient of dietary protein $\left(\% \mathrm{ADC}_{\mathrm{CP}}\right)$.
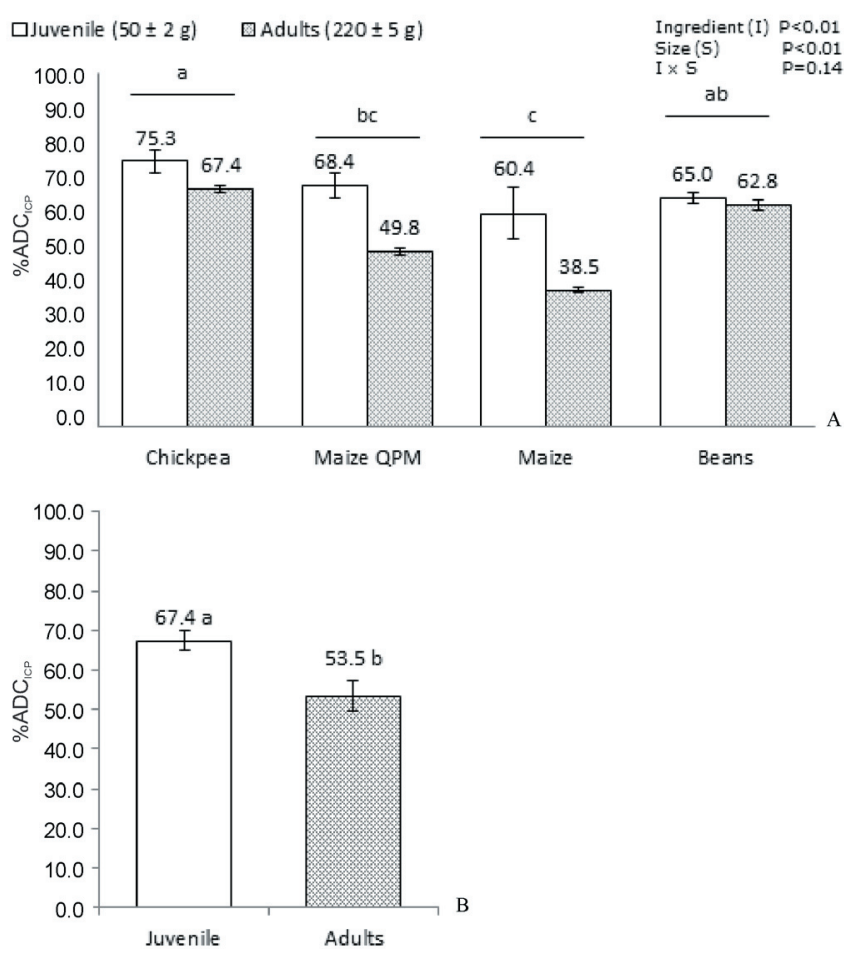

Results of the two-way ANOVA are included in the figure. Means followed by different letters are significantly different.

Figure 4 - Effect of diets (A) and tilapia size (B) on apparent digestibility coefficient of ingredients protein $\left(\% \mathrm{ADC}_{\mathrm{ICP}}\right)$. (reference diet) in juveniles and from $87.42 \%$ (maize diet) to $94.63 \%$ (reference diet) in adults. Significantly higher $\mathrm{ADC}_{\mathrm{CP}}$ was obtained with the reference diet, while the lowest $\mathrm{ADC}_{\mathrm{CP}}$ was obtained with the maize and beans diets (Figure 3). There were significant differences in $\mathrm{ADC}_{\mathrm{ICP}}$ among diets and among juveniles and adults. No significant interaction between the main factors was detected. Apparent crude protein digestibility coefficients of ingredients varied from $60.42 \%$ (maize diet) to $75.25 \%$ (chickpea diet) in juveniles and from $38.54 \%$ (maize diet) to $67.37 \%$ (chickpea diet) in adults. Significantly lower $\mathrm{ADC}_{\mathrm{ICP}}$ was obtained with the maize QPM and maize diets, while a higher $\mathrm{ADC}_{\mathrm{ICP}}$ was obtained with the chickpea and beans diets (Figure 4a). Apparent crude protein digestibility coefficient of ingredients was significantly higher in juveniles (Figure 4b).

\section{Discussion}

Apparent digestibility of dry matter and protein in the tested ingredients depended on the type of ingredient and the size of the Nile tilapia. The differences in ADC of ingredients may be explained by differences in chemical composition, which in turn is determined by the origin or processing of the feed ingredients (Köprücü and Özdemir, 2005).

Nile tilapia is apparently able to assimilate a wide variety of feedstuffs (Davies et al., 2011) and digestibility data in this study compare favourably to those obtained by studies with other freshwater tropical fish species. Nile tilapia has a relatively long gastrointestinal tract and faecal collection by natural voidance is the only realistic option for determining the apparent digestibility coefficient (Suresh, 2003; Sklan et al., 2004). Ramos et al. (2012) showed that low digestibility of cotton and cocoa bran in tilapia might be a consequence of the presence of large amounts of fibre and anti-nutritional factors in these by-products. In our study, even though beans contain high levels of protein, the $\mathrm{ADC}_{1}$ was low in juveniles and adults. Aparicio-Fernández et al. (2005) reported that beans contained $4.1 \mathrm{mg} \mathrm{g}^{-1}$ of tannins after thermal processing. The adverse effect of tannic acid on tilapia was studied by Al-Owafeir (1999), who found a significant reduction in the growth of tilapia that were fed diets containing as low as $0.27 \%$ tannic acid. However, Becker and Makkar (1998) reported that 2\% quebracho tannins (condensed tannins) was tolerated without reducing the growth of common carp, whereas similar levels of hydrolysable tannins (tannic acid) reduced acceptability of the feed after four weeks.

The presence on tannins, phytic acid, and trypsin inhibitors may be the cause of low digestibility of beans 
(Gaber, 2006). While chickpeas belong to the same family as beans, in our study, chickpeas produced the highest ADC values. According to El-Adawy (2002), cooking (heat treatments) improved the in vitro protein digestibility and protein efficiency ratio of chickpeas. The improvement in digestibility results from denaturation of protein, destruction of the trypsin inhibitor, or reduction of tannins and phytic acid (Liener, 1980; El-Adawy, 2002; Gaber, 2006). The extrusion process resulted in higher protein productive value of chickpea meal for gilthead bream Sparus aurata (Adamidou et al., 2011). In our study, heating during the extrusion process probably resulted in higher digestibility of chickpeas, as an ingredient.

Several investigations have examined the potential of maize gluten meal. The $\mathrm{ADC}_{\mathrm{DM}}$ of maize gluten meal reported by Köprücü et al. (2004), Köprücü and Özdemir (2005), and Guimarães et al. (2008) for Nile tilapia (88.0$91.0 \%)$ was higher than the our results (74-77\%). Köprücü and Özdemir (2005) suggested that the differences in ADC of nutrients and energy come from the differences in chemical composition, origin, and processing of the feed ingredients.

In our study, $\mathrm{ADC}_{\mathrm{DM}}, \mathrm{ADC}_{\mathrm{I}}$, and $\mathrm{ADC}_{\mathrm{ICP}}$ indicated higher digestibility in juveniles. Similarly, He et al. (2013) found that efficiencies of digestible protein, energy, and amino acids significantly decreased as tilapia grew larger. Alvarez-González et al. (2008) indicated that the quality and quantity of digestive enzymes of fish vary with age.

The ADC of chickpea protein (67.37-91.59\%) for Nile tilapia in general agree with the reported ADC of proteins in various feed ingredients for this species. Examples include alfalfa (66\%) and menhaden (85\%) meals (Pompa, 1982); corn (83-84\%), soybean (91-94.4\%) and sardine (86\%) meals (Hanley, 1987); defatted soybean meal (94.4\%), full fat soybean $(90 \%)$, and micronized wheat $(88.6 \%)$ (Fontainhas-Fernandes et al., 1999); anchovy meal (90\%), sunflower cakes (86-89\%), and wheat bran (75\%) (Maina et al., 2002). Part of the variability in the ADC of protein is explained by differences in chemical composition, origin, and processing of the various feed ingredients, and method of faeces collection.

\section{Conclusions}

The digestibility of the tested ingredients is generally higher in juvenile Nile tilapia. In particular, considering that the price of chickpea is lower (US $\$ 950 / t$ ) than that of fishmeal (US\$ 2388.6), we recommend using chickpea as an ingredient in their diets.

\section{Acknowledgments}

Ira Fogel of CIBNOR provided valuable editorial services. This study was supported by Secretaria de Investigación y Posgrado of the Instituto Politecnico Nacional (SIP-IPN grant 20100697) and Consejo Estatal de Ciencia y Tecnología de Sinaloa (CECyT grant 2010). Magnolia Montoya-Mejía is a recipient of a Master fellowship from CONACYT and Hervey RodríguezGonzález received support from COFAA and EDI of Instituto Politécnico Nacional

\section{References}

Adamidou, S.; Nengas, I.; Henry, M.; Ioakei Midoy, N.; Rigos, G.; Bell, G. J. and Jauncey, K. 2011. Effects of dietary inclusion of peas, chickpeas and faba beans on growth, feed utilization and health of gilthead seabream (Sparus aurata). Aquaculture Nutrition $17: 288-296$

Al-Owafeir, M. 1999. The effects of dietary saponin and tannin on growth performance and digestion in Oreochromis niloticus and Clarias garlepinus. PhD Thesis. Institute of Aquaculture, University of Stirling, UK.

Alvarez-González, C. A.; Moyano-López, F. J.; Civera-Cerecedo, R.; Carrasco-Chávez, V.; Ortiz-Galindo, J. L. and Dumas, S. 2008. Development of digestive enzyme activity in larvae of spotted sand bass Paralabrax maculato fasciatus. 1. Biochemical analysis. Fish Physiology and Biochemistry 34:373-384.

AOAC - Association of Official Analytical Chemists. 1995. Official methods of analysis of the Association of Analytical Chemist. 16th ed. AOAC International, Washington, DC.

Aparicio-Fernández, X.; Manzo-Bonilla, L. and Loarca-Piña, G. F. 2005. Comparison of antimutagenic activity of phenolic compounds in newly harvested and stored common beans Phaseolus vulgaris against aflatoxin B1. Journal of Food Science 70:73-78.

Becker, K. and Makkar, H. P. S. 1998. Effects of phorbol esters in carp (Cyprinus Carpio L). Veterinary and Human Toxicology 40:82-86.

Bolin, D. W.; King, R. P. and Klosterman, E. W. 1952. A simplified method for the determination of chromic oxide $\mathrm{Cr}_{2} \mathrm{O}_{3}$ when used as an index substance. Science 116:634-635.

Chamberlain, G. 1995. Frontiers in shrimp nutrition research. p.108-114. In: Swimming hrough Troubled Water: Proceedings of the World Aquaculture Society, San Diego, California. Browdy, C. and Hopkins, S., eds.

Cho, C. Y. and Kaushik, S. J. 1990. Nutrition energetics in fish: Energy and protein utilization in rainbow trout (Salmo gairdneri). World Review of Nutrition and Dietetics 61:32-172.

Cho, C. Y. and Slinger, S. J. 1979. Apparent digestibility measurement in feedstuffs for rainbow trout. p.239-247. In: Proceedings of the World Symposium on Finfish Nutrition and Fish Feed Technology. v.2. Halver, J. and Tiewa, K., eds. Heenemann, Berlin.

Cruz-Suarez, L. E.; Ricque-Marie, D.; Tapia-Salazar, M.; McCallum, I. M. and Hickling, D. 2001. Assessment of differently processed feed pea (Pisum sativum) meals and canola meal (Brassica sp.) in diets for blue shrimp (Litopenaeus stylirostris). Aquaculture 196:87-104.

Davies, S. J.; Abdel-Warith, A. A. and Gouveia, A. 2011. Digestibility characteristics of selected feed ingredients for developing bespoke diets for Nile tilapia culture in Europe and North America. Journal of the World Aquaculture Society 42:388-398. 
De Silva, S. S. and Perera, M. K. 1983. Digestibility of an aquatic macrophyte by the cichlid Etroplus suratensis (Bloch) with observations on the relative merits of three indigenous components as markers and daily changes in protein digestibility. Journal of Fish Biology 23:675-684.

El-Adawy, T. A. 2002. Nutritional composition and antinutritional factors of chickpeas (Cicer arietinum L.) undergoing different cooking methods and germination. Plant Foods for Human Nutrition 57:83-97.

Fagbenro, O. 1999. Apparent digestibility of various cereal grain by-products in common carp diets. Short Communication. Aquaculture International 7:277-281.

FAO Stat - Food and Agriculture Organization of The United Nations Statistics Division. 2015. Food balance. Available at: <http:// faostat3.fao.org/home/E.>. Accessed on: June 1, 2015.

Fontainhas-Fernandes, A.; Gomes, E.; Reis-Henriques, M. A. and Coimbra, J. 1999. Replacement of fish meal by plant proteins in the diet of Nile tilapia: digestibility and growth performance. Aquaculture International 7:57-67.

Gaber, M. M. 2006. Partial and complete replacement of fish meal by broad bean meal in feeds for Nile tilapia, Oreochromis niloticus, L., fry. Aquaculture Research 37:986-993.

Guimarães, L. G.; Pezzato L. E. and Barros, M. M. 2008. Amino acid availability and protein digestibility of several protein sources for Nile tilapia, Oreochromis niloticus. Aquaculture Nutrition 14:396-404.

Hanley, F. 1987. The digestibility of foodstuffs and the effects of feeding selectively on digestibility determinations in Tilapia Oreochromis niloticus L. Aquaculture 66:163-179.

Hardy, R. W. 2010. Utilization of plant protein in fish diets: effects of global demand and supplies of fishmeal. Aquaculture Research 41:770-776.

He, J. Y.; Tian, L. X.; Lemme, A.; Gao, W.; Yang, H. J.; Niu, J.; Liang, G. Y.; Chen, P. F. and Liu, Y. J. 2013. Methionine and lysine requirements for maintenance and efficiency of utilization for growth of two sizes of tilapia (Oreochromis niloticus). Aquaculture Nutrition 19:629-640.

Henken, A. M.; Kleingeld, D. W. and Tijssen, P. A. T. 1985. The effect of feeding level on apparent digestibility of dietary dry matter, crude protein and gross energy in the African catfish Clarias gariepinus (Burchell, 1822). Aquaculture 51:1-11.

Jones, P. L. and De Silva, S. S. 1997. Influence of differential movement of the marker chromic oxide and nutrients on digestibility estimations in the Australian freshwater crayfish Cherax destructor. Aquaculture 154:323-336.

Köprücü, K. and Özdemir, Y. 2005. Apparent digestibility of selected feed ingredients for Nile tilapia (Oreochromis niloticus). Aquaculture 250:308-316.

Köprücü, K.; Seven, P. T. and Tuna, G. 2004. Apparent digestibility coefficients of protein in selected feedstuff for juvenile Nile tilapia
(Oreochromis niloticus Linnaeus, 1758). Pakistan Journal of Biological Sciences 7:2173-2176.

Lee, K. J. and Dabrowski, K. 2002. High performance liquid chromatographic determination of gossypol and gossypolone enantiomers in fish tissues using simultaneous electrochemical and ultraviolet detectors. Journal of Chromatography B 779:313-319.

Liener, I. E. 1980. Heat labile antinutritional factors. p.157-170. In: Advances in legume science. Summerfield, R. J. and Bunting, A. H., eds. Kew London, Royal Botanic Gardens.

Maina, J. G.; Beames, R. M.; Higgs, D.; Mbugua, P. N.; Iwama, G. and Kisia, S. M. 2002. Digestibility and feeding value of some feed ingredients fed to tilapia Oreochromis niloticus (L.). Aquaculture Research 33:853-862.

Maynard, L. A.; Loosli, J. K.; Hintz, H. F. and Warner, R. G. 1979. Animal nutrition. 7th ed. McGraw-Hill Book Company, New York, NY.

Nieto, L. M.; Cruz-Suárez L. E. and Ricque, D. 1997. Implementación de un método para la determinación de óxido de cromo y proteína en micromuestras de alimento y heces de camarón. Programa de Maricultura, Facultad de Ciencias Biológicas, Universidad Autónoma de Nuevo León, San Nicolas de los Garza, Nuevo León, México.

Olvera-Novoa, M. A.; Martínez-Palacios, C. A. and Olivera-Castillo, L. 2002. Utilization of torula yeast (Candida utilis) as a protein source in diets for tilapia (Oreochromis mossambicus Peters) fry. Aquaculture Nutrition 8:257-264.

Pompa, T. J. 1982. Digestibility of selected feedstuffs and naturally occurring algae by tilapia. PhD dissertation. Auburn University, Auburn, Alabama.

Ramos, A. P. S.; Braga, L. G. T.; Carvalho, J. S. O. and Oliveira, S. J. R. 2012. Digestibility of agro-industrial byproducts in 200 and $300-\mathrm{g}$ Nile tilapia. Revista Brasileira de Zootecnia 41:462-466.

Richter, N.; Siddhuraju, P. and Becker, K. 2003. Evaluation of nutritional quality of moringa (Moringa oleifera Lam.) leaves as an alternative protein source for Nile tilapia (Oreochromis niloticus L.). Aquaculture 217:599-611.

Sklan, D.; Prag, T. and Lupatsch, I. 2004. Apparent digestibility coefficients of feed ingredients and their prediction in diets for tilapia Oreochromis niloticus x Oreochromis aureus (Teleostei, Cichlidae). Aquaculture Research 35:358-364.

Suresh, V. 2003. Tilapias. p.321-345. In: Aquaculture: farming aquatic animals and plants. Lucas, J. S. and Southgate, P. C., eds. Blackwell Publishing, Oxford, UK.

Ulloa Rojas, J. B. and Verreth, J. A. J. 2003. Growth of Oreochromis aureus fed with diet containing graded levels of coffee pulp and reared in two culture systems. Aquaculture 217:275-283.

Usmani, N. and Jafri, A. K. 2002. Effect of fish size and temperature on the utilization of different protein sources in two catfish species. Aqualculture Research 33:959-967.

Wee, K. L. and Wang, S. S. 1987. Nutritive value of Leucaena leaf meal in pelleted feed for Nile tilapia. Aquaculture 62:97-108. 